\title{
A NEW ECONOMIC POLICY UNCERTAINTX INDEX FOR SPAIN
}

Corinna Ghirelli, Javier J. Perez

and Alberto virtasun.

Documentos de Trabajo

N. 1906

\section{BANCODE ESPAÑA}

Eurosistema

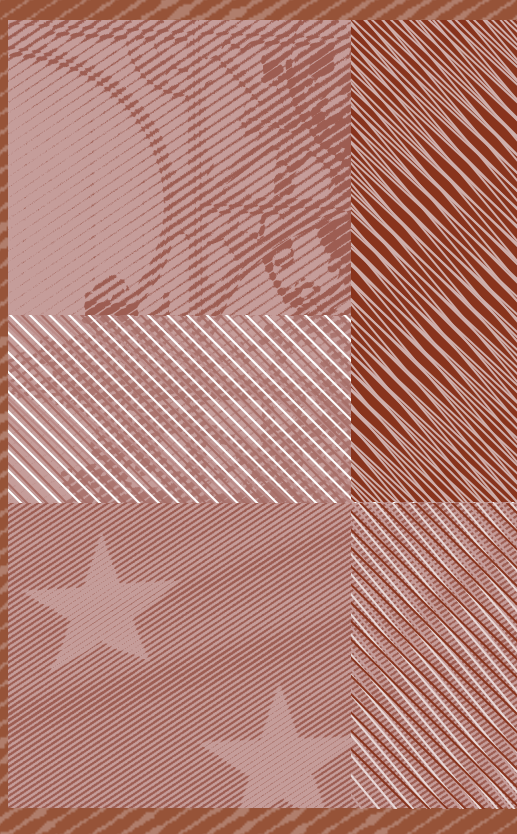


A NEW ECONOMIC POLICY UNCERTAINTY INDEX FOR SPAIN ${ }^{(*)}$

Corinna Ghirelli

BANCO DE ESPAÑA

Javier J. Pérez ${ }^{(*)}$

BANCO DE ESPAÑA

Alberto Urtasun ${ }^{(* *)}$

BANCO DE ESPAÑA

(*) The views expressed in this paper are the authors' and do not necessarily reflect those of the Banco de España or the Eurosystem. We thank Mirian Luengo for her research assistance, and seminar participants at the Banco de España for their comments. Correspondence to: Corinna Ghirelli: corinna.ghirellibde.es.

$\left.{ }^{* *}\right)$ javierperez@bde.es.

(***) aurtasun@bde.es. 
The Working Paper Series seeks to disseminate original research in economics and finance. All papers have been anonymously refereed. By publishing these papers, the Banco de España aims to contribute to economic analysis and, in particular, to knowledge of the Spanish economy and its international environment.

The opinions and analyses in the Working Paper Series are the responsibility of the authors and, therefore, do not necessarily coincide with those of the Banco de España or the Eurosystem.

The Banco de España disseminates its main reports and most of its publications via the Internet at the following website: http://www.bde.es.

Reproduction for educational and non-commercial purposes is permitted provided that the source is acknowledged.

C BANCO DE ESPAÑA, Madrid, 2019

ISSN: 1579-8666 (on line) 


\section{Abstract}

We construct a new Economic Policy Uncertainty (EPU) index for Spain, building on the influential methodology of Baker, Bloom and Davis (2016), and compare it with the EPU for Spain that these authors provide. We refine the index in several dimensions: we expand the headline newspaper coverage from 2 to 7 , including economic-financial ones, use a much richer set of keywords to form the search expressions, and cover a longer sample period. Two results stand out: (i) the new index presents a more consistent chronology of economic policy events; (ii) the macroeconomic effects of uncertainty shocks identified from the new index yield significant negative responses of GDP, private consumption and private investment, compared to mute responses obtained using the original one. Beyond the results for the Spanish case, our results suggest that, in addition to the richness of the keywords in the search expressions, widening the press and time coverage is key to improve the quality of the aggregate EPU index.

Keywords: economic uncertainty, policy uncertainty, uncertainty shocks.

JEL classification: D8; C43; E2; E3. 


\section{Resumen}

En este documento elaboramos un nuevo índice de incertidumbre sobre las políticas económicas (Economic Policy Uncertainty, EPU) para España, siguiendo la influyente metodología de Baker, Bloom y Davis (2016), y lo comparamos con el elaborado por estos autores. El nuevo índice incorpora mejoras metodológicas, entre las que destacan, en primer lugar, la mayor cobertura de periódicos de referencia para el análisis textual (de dos a siete, entre los que se incluye prensa económico-financiera); en segundo lugar, el uso de expresiones de búsqueda (palabras clave) más ricas y ajustadas al uso del español, $y$, finalmente, el uso de una muestra temporal más amplia. El nuevo índice proporciona una medición de la incertidumbre que captura los principales eventos de la historia reciente que se podrían asociar con aumentos de la incertidumbre sobre las políticas económicas. Asimismo, los aumentos inesperados de la incertidumbre de acuerdo con este índice se encuentran asociados a caídas de la actividad económica, del consumo privado y de la inversión empresarial.

Palabras clave: incertidumbre económica, incertidumbre sobre las políticas económicas, shocks de incertidumbre.

Códigos JEL: D8; C43; E2; E3. 


\section{Introduction}

The theoretical and empirical literature shows that heightened economic uncertainty can harm economic activity. Nevertheless, being "uncertainty" a non-observable concept, a number of empirical strategies have been developed in the literature to proxy it (see e.g. Castelnuovo et al. (2017), and the references quoted therein). The most influential methodology to compute such proxies is the so-called Economic Policy Uncertainty (EPU) index of Baker et al. (2016) (BBD henceforth). ${ }^{12}$

BBD construct indexes of economic policy uncertainty based on newspaper coverage frequency for the US and some other countries. ${ }^{3}$ For each country, they select several newspapers and count the number of articles that contain terms referring to three categories: economy, policy, and uncertainty. ${ }^{4}$ They scale the raw count by the total number of articles in the same newspaper/month, standardize the monthly series of scaled counts, average them across the newspapers, and rescale the resulting index to mean 100, to obtain the monthly EPU index. For the US case, they rely on a large press and time coverage. ${ }^{5}$ For European countries, they restrict the press coverage to two newspapers per country, and draw on the following newspapers: Le Monde and Le Figaro for France, Handelsblatt and Frankfurter Allgemeine Zeitung for Germany, Corriere Della Sera and La Repubblica for Italy, El Mundo and El País for Spain, and The Times of London and Financial Times for the United Kingdom. The time coverage varies case by case, and in Spain starts from January 2001.

In this paper we provide a new EPU index for Spain, building on the methodology of $\mathrm{BBD}$, so that it is more in line with the index $\mathrm{BBD}$ constructed for the US. We expand the latter in several relevant dimensions, namely: (i) we expand the headline newspaper

\footnotetext{
${ }^{1}$ Other types of uncertainty indicators are available in the literature. See, among others, indexes based on forecast errors (Jurado et al., 2015; Rossi and Sekhposyan, 2015; Huang et al., 2018; Shin et al., 2018; Sakutukwa and Yang, 2018), on Google searches (Donadelli, 2015), on disagreement between agents' expectations (Bachmann et al., 2013).

${ }^{2}$ The BBD EPU index has been borrowed in a number of empirical applications: e.g. Meinen and Roehe (2017); Fontaine et al. (2017); Caggiano et al. (2017); Colombo (2013), or has inspired newly constructed indexes (like Shoag and Veuger (2016) for the US states). In turn Azqueta-Gavaldon (2017) propose creating a news-based EPU index by employing an unsupervised algorithm.

${ }^{3}$ See also Davis (2016), and the dedicated webpage http://www.policyuncertainty.com/.

${ }^{4}$ Counts are based on Boolean searches, in which the search expression is a combination of keywords and logical operators (e.g. and, or, not), and whose result is the count of items satisfying the search expression. This search can be implemented with web search engines and does not require researchers having access to the underlying items.

${ }^{5}$ They consider 10 large newspapers: USA Today, the Miami Herald, the Chicago Tribune, the Washington Post, the Los Angeles Times, the Boston Globe, the San Francisco Chronicle, the Dallas Morning News, the New York Times, and the Wall Street Journal. As for the time coverage, the index starts in January 1985.
} 
coverage from 2 to 7, including economic-financial ones; (ii) we use a much richer set of keywords to form the search expressions; (iii) we cover a longer sample period (from January 1997 instead of 2001). In addition, we provide estimates of the macroeconomic effects of uncertainty shocks.

Two results stand out: (i) the new index presents a more consistent chronology of economic policy events; (ii) the macroeconomic effects of uncertainty shocks measured from the new index yield significant negative responses of GDP, private consumption and private investment, compared to mute responses obtained using the original one.

In addition, we investigate the relative role of richness of keywords, press and time coverage in improving the quality of the index. Finally, we study the heterogeneity of macroeconomic responses to unexpected shocks in different versions of the EPU index obtained by considering a sub-set of the press coverage (i.e. generalist versus business newspapers), or specific newspapers. From a general point of view, our results suggest that, in addition to the richness of the keywords in the search expressions, widening the press and time coverage is key to improve the quality of the aggregate EPU index.

In the rest of the paper we explain how we build our index (Section 2), our empirical exercise (Section 3), and some conclusions (Section 4).

\section{Building the index}

We consider 7 relevant Spanish national newspapers: El País, El Mundo, La Vanguardia, ABC, Expansión, Cinco Días, and El Economista. The first 4 newspapers are the largest and most read generalist newspapers in Spain, ${ }^{6}$ while Expansión, Cinco Días, and El Economista are the three headline Spanish business newspapers. We focus on the printed editions of these newspapers and ignore their online versions. ${ }^{7}$ All searches are carried out using the Dow Jones' Factiva service. For each newspaper, we conduct our search from the first date in which the newspaper is collected in the Dow Jones' Factiva database, starting from January 1997. ${ }^{\text {Table }} 1$ provides the time coverage of each newspaper.

\footnotetext{
${ }^{6}$ According to Información y Control de Publicaciones (OJD), - a private firm which audits the diffusion of daily newspapers - these newspapers are ranked first in terms of average printed copies for the audited period 7/2017-6/2018 (excluding sport newspapers). See https://www.ojd.es.

${ }^{7}$ Note, press online editions spread only in the most recent years, while we consider quite a substantial time span. Ignoring the digital press ensures homogeneity in our index. In addition, the digital editions publish reduced versions of the most important printed articles, which may lead to double counting.

${ }^{8}$ We restrict all queries to articles whose content is related to Spain, based on Factiva's indexation. We replicated the index ignoring this condition and got very similar results. Results available upon request.
} 
Our search counts the number of articles containing simultaneously at least one keyword related to the categories of "uncertainty", "economy", and "policy". In particular, we focus the following keywords (in Spanish language):

- Uncertainty: inciert* or incertidumbr* or inestabl* or inestabilidad or inestabilidades or riesgo or riesgos;

- Economy: economic* or economía;

- Policy: Parlamento or Moncloa or gobierno central or Hacienda or Comisión Europea or déficit or presupuest* or gasto público or gastos públicos or deuda pública or deudas públicas or política fiscal or políticas fiscales or política monetaria or políticas monetarias or ((el or de or del or un or por or este or ese or aquel) w/1 impuesto or impuestos $)^{9}$ or Banco Central Europeo or BCE or Banco de España or BdE or legislación or legislaciones or reforma or reformas or norma or normas or normativ* or regulación or regulaciones or reglamento or reglamentos or ley or leyes.

The construction of the index follows closely the procedure used by BBD, as described in the previous section. In addition to the aggregate EPU index, we also compute a Generalistnews and a Business-news EPU index by restricting the press coverage accordingly. ${ }^{10}$ Finally, we construct newspaper-specific EPU indexes. All these indexes are shown in Figure 1. As regards the Generalist-news versus the Business-news indexes, they behave quite similarly (Figure 1h). The only noticeable, visual difference is that the former is shifted downwards in the first years and, perhaps more importantly, it increases already at the start of 2006 and remains at a higher level throughout the biennium 2006-2007, anticipating the financial crisis. By contrast, the Generalist-News EPU index starts rising only in 2008.

\footnotetext{
${ }^{9}$ As for the word impuesto, we impose in the search expression that it is preceded by articles, propositions or demonstrative adjectives because we want to ensure that we capture sentences in which impuesto is a noun (e.g. meaning taxes) and not the past participle of the verb imponer. This is not necessary when searching for its plural form impuestos.

${ }^{10}$ The Generalist-news EPU index is based on El País, El Mundo, La Vanguardia, and ABC. The Businessnews EPU index is based on Expansión, Cinco Días, and El Economista.
} 
Table 1: Date range by newspaper

\begin{tabular}{lccc}
\hline Newspaper & First obs. & Last obs. & Nr. months \\
\hline El País & $2001 \mathrm{~m} 1$ & $2018 \mathrm{~m} 6$ & 210 \\
El Mundo & $1997 \mathrm{~m} 1$ & $2018 \mathrm{~m} 6$ & 258 \\
Expansión & $1997 \mathrm{~m} 1$ & $2018 \mathrm{~m} 6$ & 258 \\
Abc & $1997 \mathrm{~m} 6$ & $2018 \mathrm{~m} 6$ & 253 \\
Cinco Dias & $1997 \mathrm{~m} 1$ & $2018 \mathrm{~m} 6$ & 258 \\
El Economista & $2008 \mathrm{~m} 4$ & $2018 \mathrm{~m} 6$ & 123 \\
La Vanguardia & $1997 \mathrm{~m} 5$ & $2018 \mathrm{~m} 6$ & 254 \\
\hline
\end{tabular}

Our main EPU indicator is shown in Figure 2a. Since uncertainty is unobserved, understanding whether an uncertainty proxy is an appropriate measure is not obvious. A graphical inspection allows to check whether the uncertainty measure increases in periods that are generally associated to periods of higher uncertainty. The new EPU index increases at the time of the terrorist attacks of 11 September 2001 in US, the Lehman Brothers bankruptcy in September 2008 or the Greek bailout in April 2010. In particular, the new EPU shows the highest spike in June 2012, when Spain asked for a financial sector support package from the European institutions, and decreases afterwards. Also, in the most recent period, the index increases again during the Catalan crisis in October 2017.

A comparison between the new EPU index and the original BBD's EPU index (named EPU-BBD hereafter) is provided in Figure 2b. According to this figure, the EPU-BBD index is more volatile than the new one, showing some important spikes that cannot be associated to any relevant policy-related historical event. For instance, it drastically increases in June and October 2002, which do not coincide to any significant episode. As the figure shows, these spikes do not show up in the new EPU index. Another example is the dramatic increase displayed by the EPU-BBD index in March 2003, at the time of the Iraq invasion. This is the largest spike in the entire series. Although this event could have certainly reflected Spainrelated economic policy uncertainty, it is hard to associate it with the sharpest increase in the series. The new EPU index, in contrast, presents only a slight increase at that date. From 2004 onwards, both indexes follow a similar evolution, overall, even though they present different dating of uncertainty spikes (and associated intensity) for some key episodes. Of particular notice is the increase in economic policy uncertainty at the time of the recapitalization of the Spanish banking sector, a major event in the Spanish recent economic history, that is much more marked, in relative terms, by the new EPU index. 


\section{Empirical exercise}

We identify the macroeconomic effects of EPU shocks by means of VAR models: $X_{t}=$ $\Pi(L) X_{t}+\epsilon_{t}$, where $X_{t}$ is a set of endogenous variables, $\Pi$ is a matrix of VAR coefficients capturing the dynamics of the system, and $\epsilon_{t}: N(0, \Omega)$ is the vector of reduced-form residuals having zero-mean and variance-covariance matrix $\Omega$. The VAR models are estimated by OLS. In each model we include lags according to the optimal lag length based on the Schwarz Information Criterion.

To make sure that EPU shocks are orthogonal to the other stochastic elements in the econometric framework, we model the impulse vector responsible of the one-impact response of the variables in the vector $X_{t}$ by means of a Cholesky decomposition of the reducedform variance-covariance matrix $\Omega$. The variables in $X_{t}$ are the following: EPU (levels), the Spanish 10-year sovereign debt spread over the German Bund, real GDP (quarterly growth rates) [in turn, Real Households' aggregate consumption, or Real Capital Goods Investment], inflation rate (quarterly growth rates of CPI), and a variable controlling for global uncertainty as proxied by the global EPU index of Baker et al. (2016), which we assume to be exogenous. ${ }^{11}$

In Figures 3 and 4 we show the main results of the analysis, by mean of the responses of GDP, the spread, household's consumption and investment. ${ }^{12}$

Figure 3 compares the responses of GDP, the spread, consumption and investment for an unexpected shock of one standard deviation in the Spanish uncertainty indicator, as measured alternatively by BBD's EPU index (EPU-BBD) and our new indicator (EPUNEW). In the latter case we run the VAR model for the period 1997Q1:2018Q6. When instead we use the EPU-BBD index, we focus on the sample period 2001Q1:2018Q6, since the EPU-BBD index is available from January 2001 onwards. We do so because widening the time coverage increases the precision of results. ${ }^{13}$

\footnotetext{
${ }^{11}$ The global EPU Index is a GDP-weighted average of national EPU indices for 20 countries: Australia, Brazil, Canada, Chile, China, France, Germany, Greece, India, Ireland, Italy, Japan, Mexico, the Netherlands, Russia, South Korea, Spain, Sweden, the United Kingdom, and the United States. It is available at http://www.policyuncertainty.com. Based on our tests, it is exogenous in Granger's sense. Results available upon request.

${ }^{12} \mathrm{We}$ also perform a number of robustness checks. In particular, our results are robust to: (i) ordering uncertainty last in the vectors, which enables us to control for the possible role played by contemporaneous variables in the VAR in affecting uncertainty; (ii) modeling different VAR lags. All these checks are available upon request.

${ }^{13} \mathrm{We}$ also compute the impulse response functions based on a VAR model in which the EPU-NEW indicator is constructed considering the period from January 2001 onwards. Results are qualitatively similar to the ones obtained with the EPU-NEW based on the entire time coverage, although less significant. GDP responses for both cases are shown in Figure 5. The other responses are available upon request.
} 
Figure 1: Newspaper-specific EPU indexes.

(a) El País

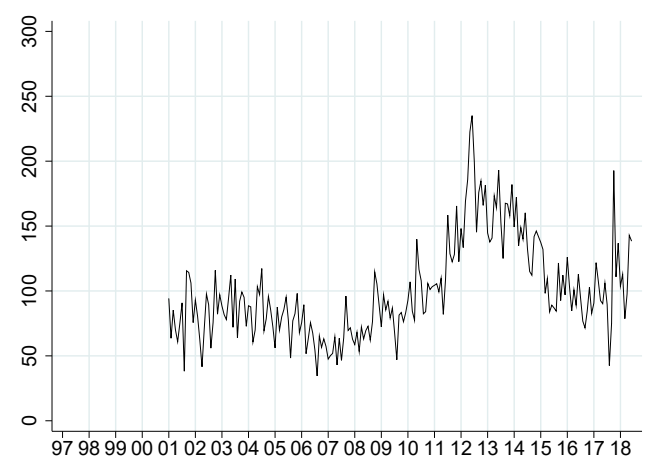

(c) $A b c$

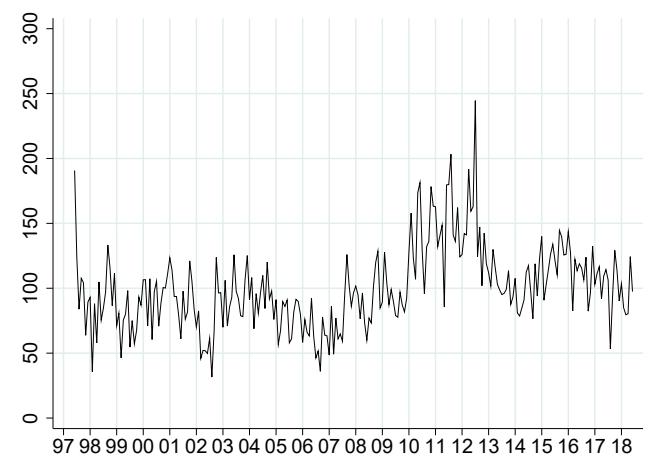

(e) Expansión

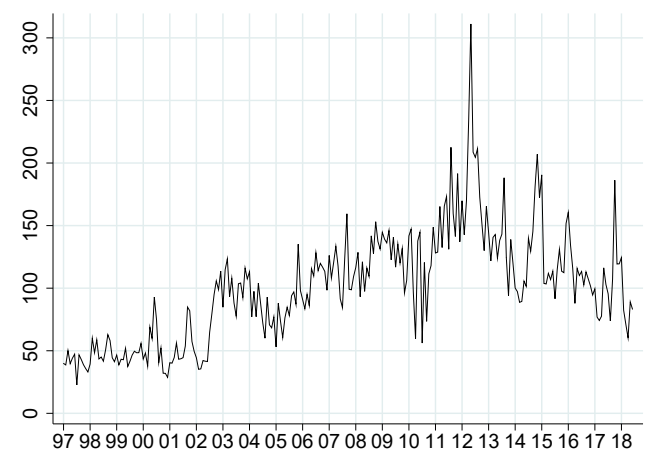

(g) El Economista

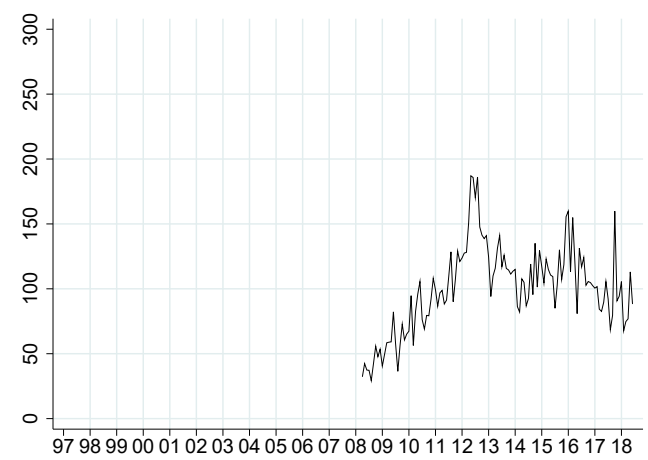

(b) El Mundo

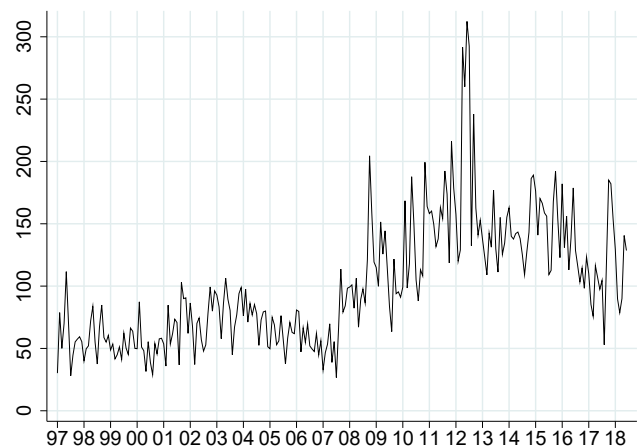

(d) La Vanguardia

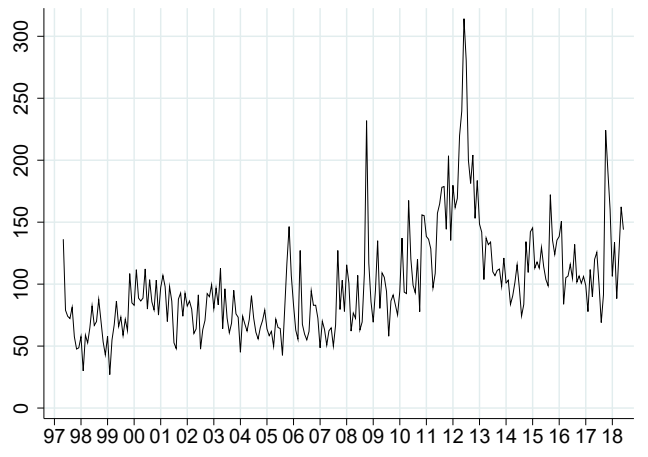

(f) Cinco Dias

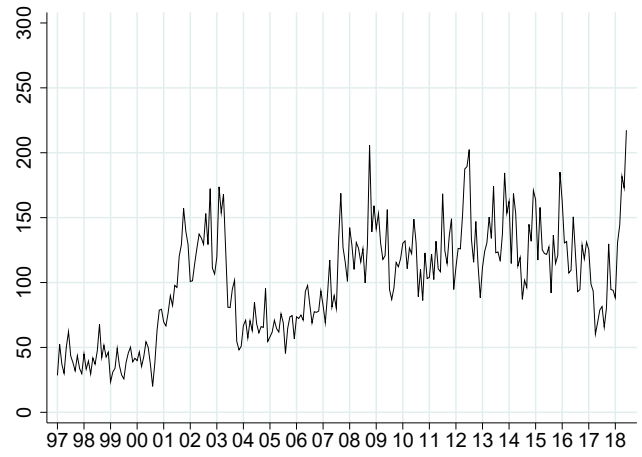

(h) Generalist vs Business News

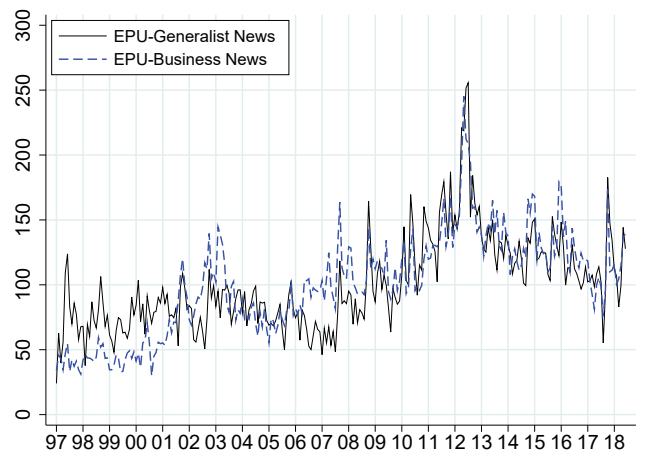

Notes: Figures (a)-(g): each series is standardized to unit standard deviation and rescaled to mean 100. Figure (h): EPU-Generalist News comprises El País, El Mundo, La Vanguardia, and ABC; EPU-Business News is based on Expansión, Cinco Días, and El Economista. 
Figure 2: Narrative of main events in EPU indexes.

(a) New EPU index.

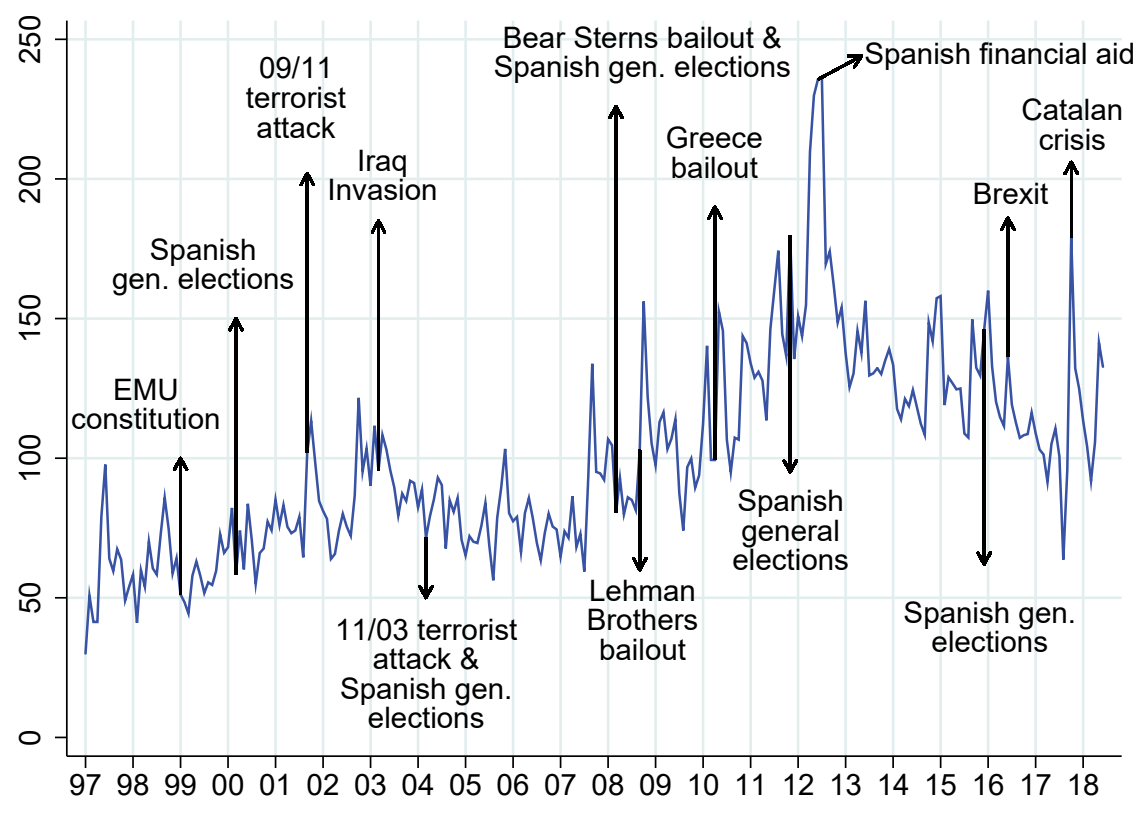

(b) Comparison with EPU-BBD index

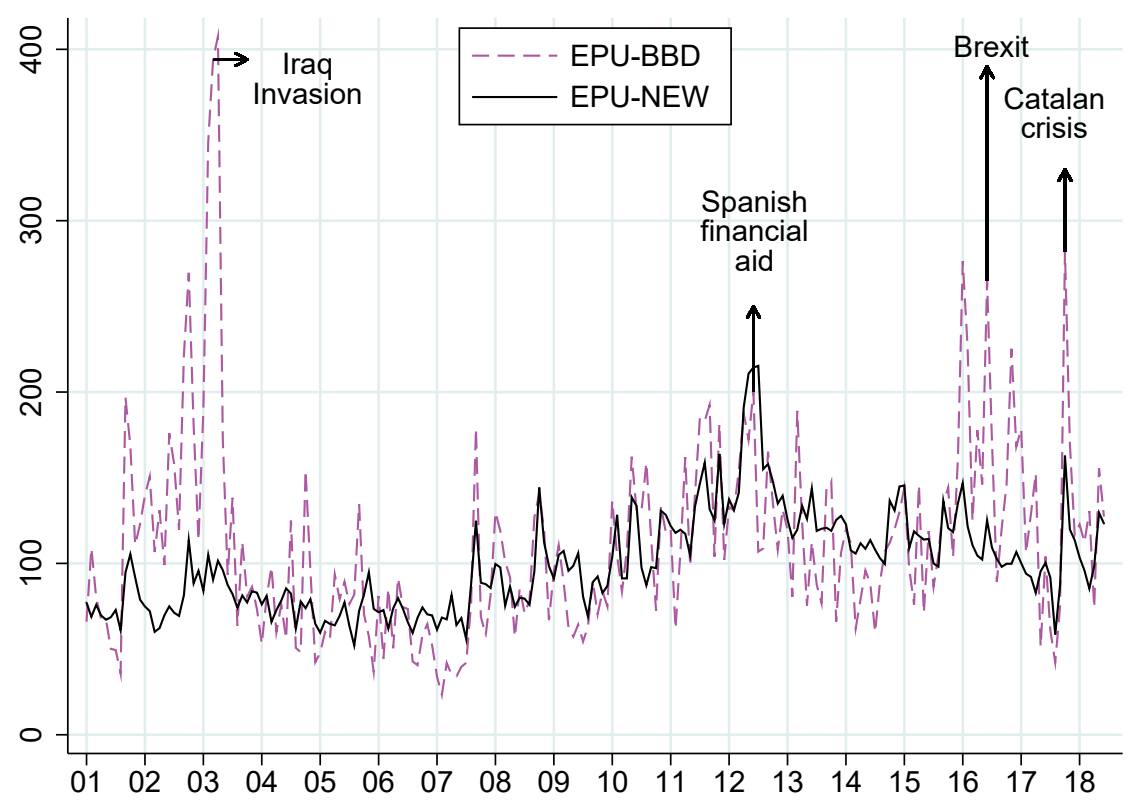

Notes: EPU-BBD: the EPU index constructed by Baker et al. (2016) and available at http://www. policyuncertainty.com. EPU-NEW: own calculation, computed using the same time coverage as the EPU-BBD (from January 2001 onwards). 
Turning to the EPU-NEW case, an unexpected increase in uncertainty generates a significant drop in GDP that lasts for 5 quarters. The initial fall in the GDP amounts to about 0.08 percentage points $(p p)$ in the second and third quarter, and gradually fades away. As for the spread's response, it jumps from the first quarter by 16 basic points and the positive effect persists up to 4 quarters. Both private consumption and investment fall significantly and then gradually come back to their initial value. The response of investment is more pronounced than the one in private consumption (about $0.9 p p$ and $0.25 p p$ in the second quarter, respectively) and then vanishes quickly afterwords, while the fall in private consumption is more prolonged and remains significant at $5 \%$ level until quarter 5 . By contrast the responses of an unexpected shock in the EPU-BBD index is zero in all cases. Only the response in the spread is positive but not statistically significant and of a much lower magnitude (of about 4 basic points) compared to the results based on the EPU-NEW.

Our second result is reported in Figure 4, which shows a similar exercise considering the Business news and Generalist news EPU indexes. In both cases, we use the sample period 1997Q1:2018Q2. The impulse response functions of the macroeconomic variables of interest show qualitatively similar patterns, which are also in line with the aforementioned results obtained with our aggregate EPU index. The responses in GDP, private consumption and investment are very similar between each other. The spread's response after a shock in the Generalist news EPU index is similar but somewhat more persistent relatively to the one of the Business news EPU index. This result is expected since, as mentioned in a previous section, both EPU indexes display a broadly similar behavior over time (Figure 1h).

Next, we investigate the relative role of (i) richness of keywords, (ii) press coverage and (iii) time coverage in driving the results. We focus on GDP responses. Results are shown in Fig. 5, which compares GDP responses from shocking alternative EPU versions in which we vary one of the aforementioned dimensions at a time, moving from the EPU-BBD to our new index. For instance, the line EPU-NEW (OLD COV.) refers to an index which we construct using our keywords but fixing the press and time coverage to those of the EPUBBD index. Therefore, comparing this response to the one of EPU-BBD allows to check the relevance of enriching the keywords in the search queries. Similarly, for the line EPU-NEW (NEW COV.) we use our keywords and press coverage, but keep the time coverage as in the EPU-BBD index. By comparing responses from shocks in EPU-NEW (OLD COV.) and EPU-NEW (NEW COV.), we get a sense of the contribution of widening the press coverage when constructing the index. Finally, comparing results of EPU-NEW (NEW COV.) with 
those obtained with EPU-NEW allows us to test the importance of increasing the time span. According to the figure, all dimensions (i)-(iii) are important, since they all contribute to obtain the expected negative sign in the GDP responses. In addition, the time coverage is key to improve the precision of the estimates and to yield significant results.

In our last exercise we compute impulse response functions of real GDP after a shock in the newspaper-specific EPU indexes (see Figure 6). ${ }^{14}$ In most cases, results are qualitatively similar to the responses we obtained with the aggregate EPU index. The only exceptions are results based on El País and El Economista, which show responses with the opposite sign (although not significant). While we do not give much importance to results based on $\mathrm{El}$ Economista given the small time period available (since January 2008), results based on El País, by far the largest and most read newspaper in Spain, are not expected. For all other newspapers, results show the correct negative sign both when considering the full sample period and when focusing on the period from January 2001 onwards. This confirms that the puzzling responses obtained when shocking the EPU based on El País are not due to the shorter time coverage available. From a general point of view, this confirms that maximizing the press coverage is key when constructing these types of text-based indicators.

\section{Conclusions}

The aim of this paper is to improve the influential Economic Policy Uncertainty (EPU) index first constructed by Baker et al. (2016) for Spain. While we follow closely the methodology used by these authors, we refine the index in a number of dimensions. First, we widen the press coverage by considering 7 national Spanish newspapers, including the 3 Spanish business ones, and expand the time window backwards. Second, we substantially enrich the keywords used in the search expression, especially the ones related to the category of "uncertainty" and "policy", which we adapt to the Spanish case. Comparing both indexes against the time-line of relevant events, the evolution of our new EPU index reflects in a more convincing way the chronology of economic policy-related events in the country over the past decades.

\footnotetext{
${ }^{14}$ In each case, the sample period of the VAR models depends on the availability of each specific newspaper. As a robustness check, we also perform the same exercise by constructing each newspaper-specific EPU index considering the period from January 2001 onwards. We do this for the newspapers that are available before January 2001, i.e.: Expansión, Cinco Días, El Mundo, La Vanguardia, and ABC. The comparison in the GDP responses is shown Figure 6.
} 
In addition, we run an empirical application in which we investigate the macroeconomic effects of our new EPU index by means of SVAR models. The following results are worth noticing. First, an unexpected shock in our new EPU index leads to a negative response in GDP, private consumption, and investment, which is consistent with theoretical expectations. By contrast, the same model yields negligible effects after a shock in BBD's index. In addition, we study the relative contribution of enriching the keywords and widening the press and time coverage when constructing the index. We find that all these dimensions are key to improve the quality of the EPU index. Last, we investigate the heterogeneity of macroeconomic responses to unexpected shocks in different versions of the EPU index obtained by considering a sub-set of the press coverage (i.e. generalist newspapers versus business newspapers), or specific newspapers.

From a general point of view, our results suggest that, in addition to the richness of the keywords in the search expressions, widening the press and time coverage is key to improve the quality of the aggregate EPU index. 


\section{References}

Bachmann, R., S. Elstner, and E. R. Sims (2013). Uncertainty and Economic Activity: Evidence from Business Survey Data. American Economic Journal: Macroeconomics 5(2), $217-49$.

Baker, S. R., N. Bloom, and S. J. Davis (2016). Measuring Economic Policy Uncertainty*. The Quarterly Journal of Economics 131(4), 1593-1636.

Caggiano, G., E. Castelnuovo, and J. M. Figueres (2017). Economic policy uncertainty and unemployment in the United States: A nonlinear approach. Economics Letters 51, 31-34.

Castelnuovo, E., G. Lim, and G. Pellegrino (2017). A Short Review of the Recent Literature on Uncertainty. Australian Economic Review 50(1), 68-78.

Colombo, V. (2013). Economic policy uncertainty in the US: Does it matter for the Euro area? Economics Letters 121(1), 39-42.

Davis, S. J. (2016, October). An Index of Global Economic Policy Uncertainty. Working Paper 22740, National Bureau of Economic Research.

Donadelli, M. (2015). Google search-based metrics, policy-related uncertainty and macroeconomic conditions. Applied Economics Letters 22(10), 801-807.

Fontaine, I., L. Didier, and J. Razafindravaosolonirina (2017). Foreign policy uncertainty shocks and US macroeconomic activity: Evidence from China. Economics Letters 155, $121-125$.

Huang, Z., C. Tong, H. Qiu, and Y. Shen (2018). The spillover of macroeconomic uncertainty between the U.S. and China. Economics Letters 171, 123 - 127.

Jurado, K., S. C. Ludvigson, and S. Ng (2015). Measuring Uncertainty. American Economic Review $105(3), 1177-1216$.

Meinen, P. and O. Roehe (2017). On measuring uncertainty and its impact on investment: Cross-country evidence from the euro area. European Economic Review 92, 161-179. 
Rossi, B. and T. Sekhposyan (2015). Macroeconomic Uncertainty Indices Based on Nowcast and Forecast Error Distributions. American Economic Review 105(5), 650-55.

Sakutukwa, T. and H.-S. Yang (2018). The role of uncertainty in forecasting employment by skill and industry. Applied Economics Letters 25(18), 1288-1291.

Shin, M., B. Zhang, M. Zhong, and D. J. Lee (2018). Measuring international uncertainty: The case of Korea. Economics Letters 162, 22-26.

Shoag, D. and S. Veuger (2016). Uncertainty and the geography of the Great Recession. Journal of Monetary Economics 84, 84-93. 
Figure 3: VAR results: EPU-BBD vs EPU-NEW.

(a) GDP response to EPU.

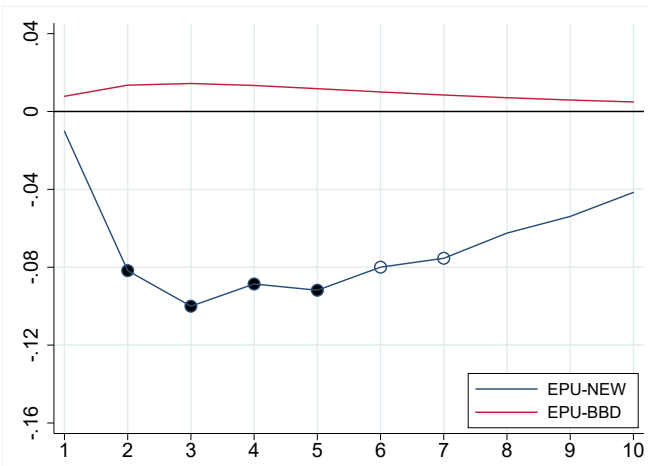

(c) Consumption response to EPU.

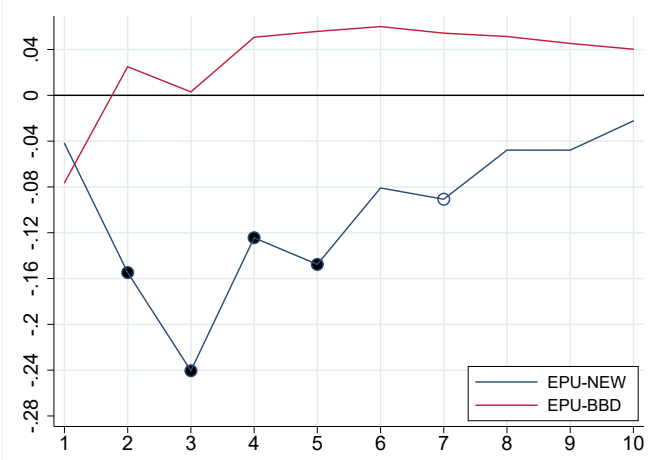

(b) Spread response to EPU.

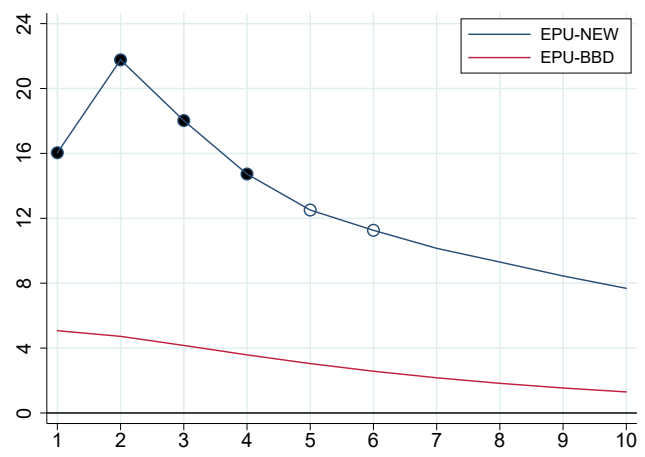

(d) Investment response to EPU.

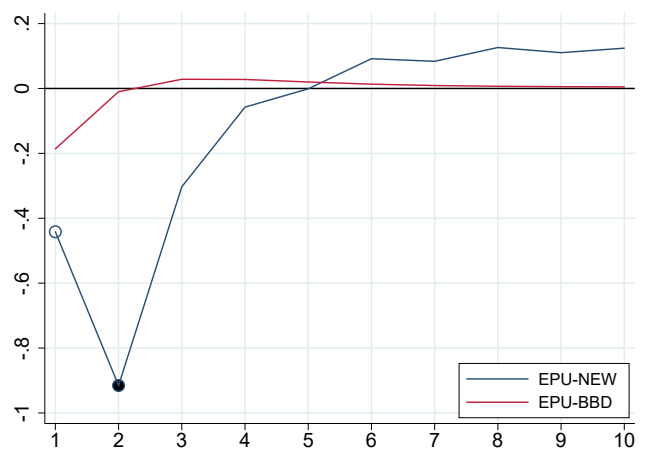

Notes: Each graph shows the impulse response function up to 10 quarters to a positive shock of one standard deviation in the EPU index. Full circles indicate statistical significance at 5\%; empty circles indicate statistical significance at $10 \%$; solid line indicates no statistical significance.

EPU-BBD: EPU index constructed by Baker et al. (2016) and available at http://www . policyuncertainty.com. EPU-NEW: own calculation.

VAR models include as endogenous variables the Spanish EPU index (EPU-BBD/EPU-NEW, alternatively), the Spanish sovereign debt spread over the German Bund, GDP/consumption/investment, and a price index; in addition, it includes as exogenous variable the global EPU index. Models with EPU-BBD (EPU-NEW) consider the period 2001Q1:2018Q2 (1997Q1:2018Q2). Quarterly data used. 
Figure 4: VAR results: Generalist news vs Business news EPU index.

(a) GDP response to EPU.

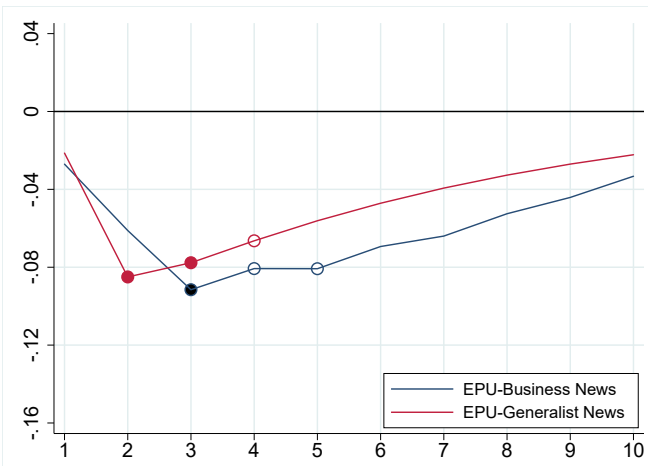

(c) Consumption response to EPU.

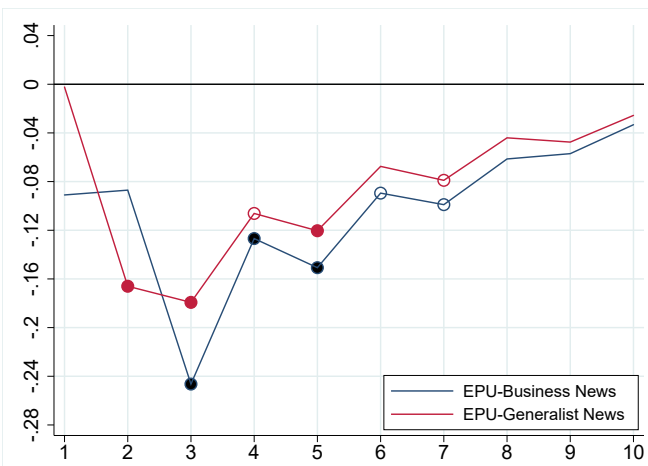

(b) Spread response to EP.U

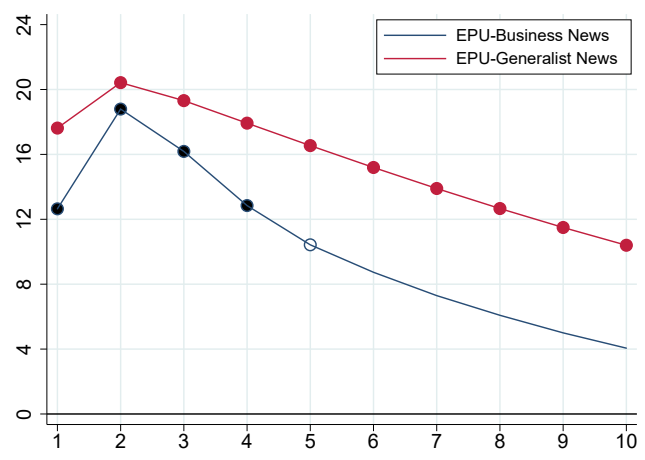

(d) Investment response to EPU.

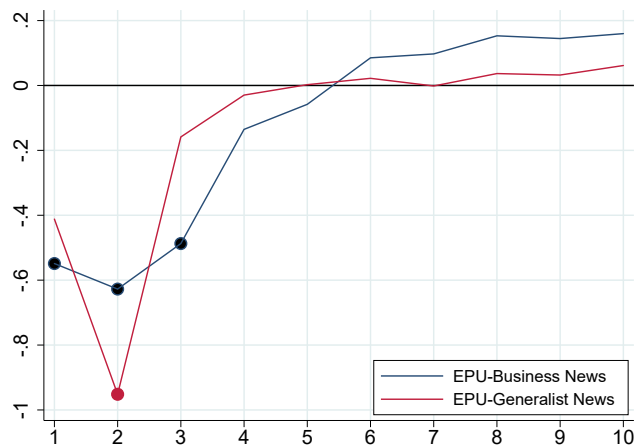

Notes: Each graph shows the impulse response function up to 10 quarters to a positive shock of one standard deviation in the EPU index. Full circles indicate statistical significance at 5\%; empty circles indicate statistical significance at 10\%; solid line indicates no statistical significance. VAR models include as endogenous variables the Spanish EPU index (Generalist news and Business news EPU index, alternatively), the Spanish sovereign debt spread over the German Bund, GDP/consumption/investment, and a price index; in addition, it includes as exogenous variable the global EPU index. All models consider the period 1997Q1:2018Q2. Quarterly data used. 
Figure 5: GDP response to EPU: Relative contribution of richness of keywords, and press and time coverage in improving the index.

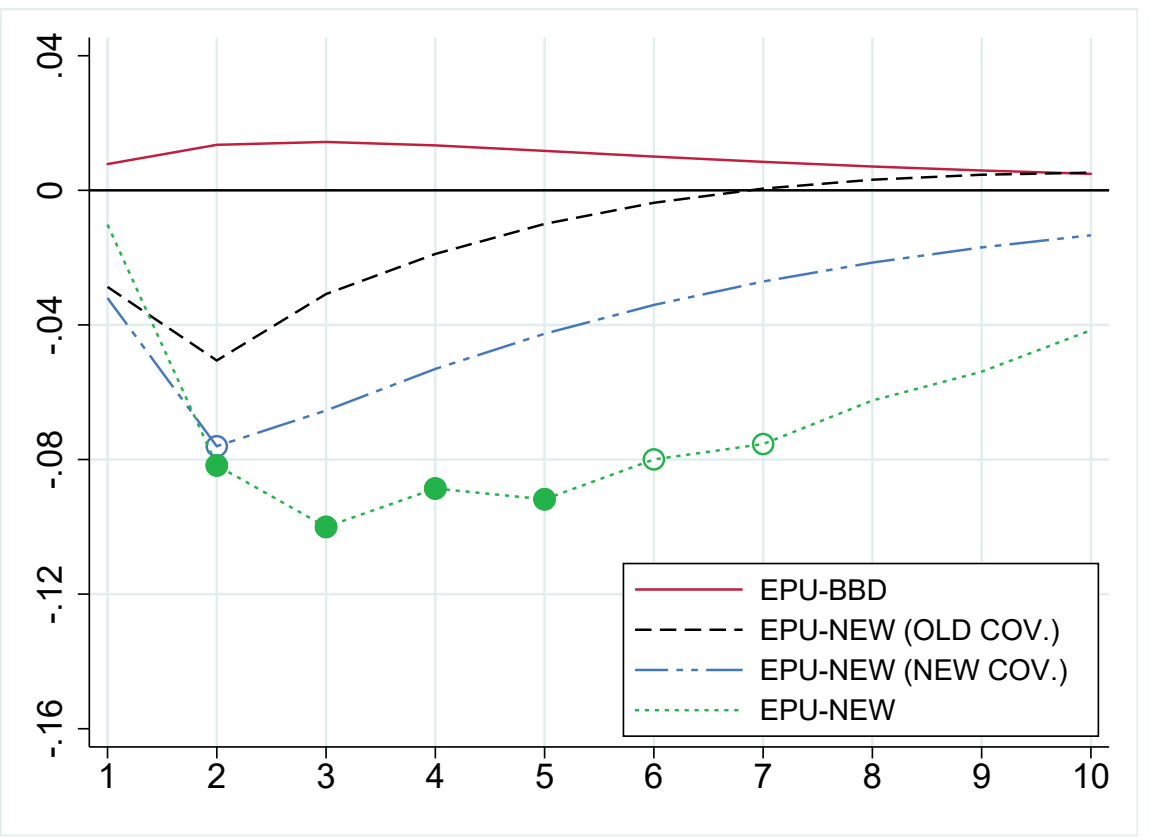

Notes: The graph shows the GDP impulse response function up to 10 quarters to a positive shock of one standard deviation in the EPU index. Full circles indicate statistical significance at 5\%; empty circles indicate statistical significance at $10 \%$; no circle indicates no statistical significance.

EPU-BBD: EPU index constructed by Baker et al. (2016) and available at http://www . policyuncertainty.com.

EPU-NEW (OLD COV.): own calculation. It is the EPU index using our keywords, restricting the press coverage to El País and El Mundo, and the time coverage from January 2001 onwards.

EPU-NEW (NEW COV.): own calculation. It is the EPU index using our keywords and our press coverage, restricting the time coverage from January 2001 onwards.

EPU-NEW INDEX: own calculation. It is the EPU index using our keywords and our press coverage, widening the time coverage from January 1997 onwards.

VAR models include as endogenous variables one of the aforementioned Spanish EPU indexes, the Spanish sovereign debt spread over the German Bund, GDP, and a price index; in addition, it includes as exogenous variable the global EPU index. All models models consider the period 2001Q1:2018Q2 a part from the one with EPU-NEW which considers 1997Q1:2018Q2. Quarterly data used. 
Figure 6: VAR results: GDP responses to shocks in Newspaper-specific EPU indexes.

(a) El País.

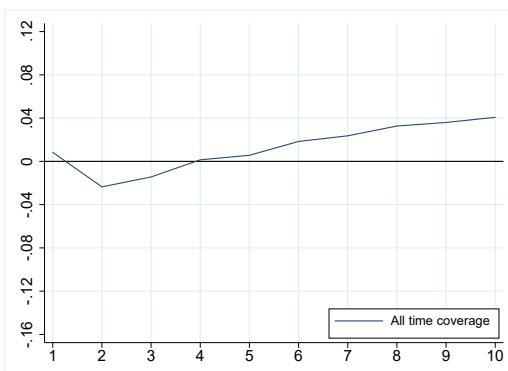

(c) $A b c$.

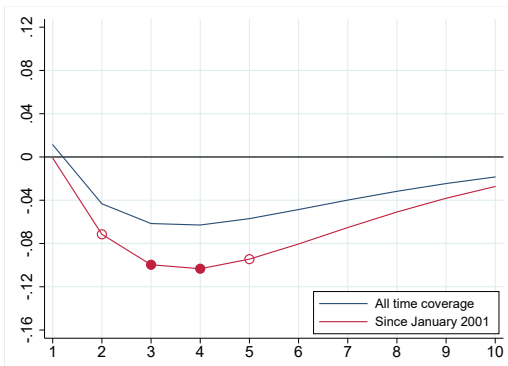

(e) Expansión.

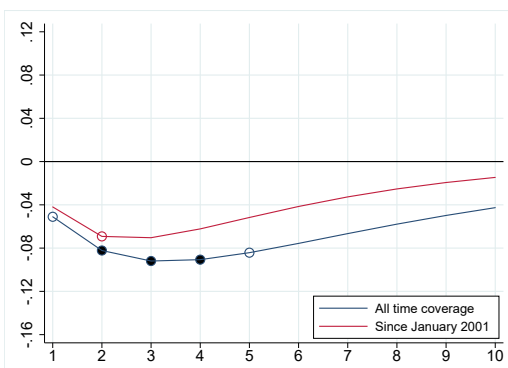

(b) El Mundo.

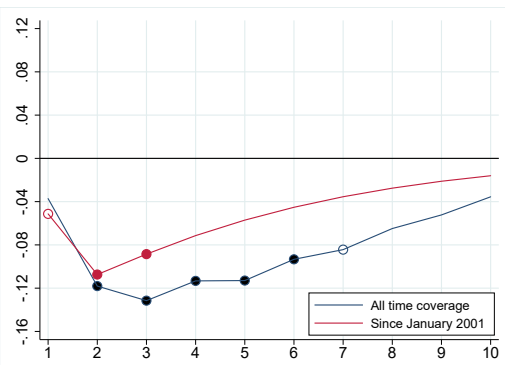

(d) La Vanguardia.

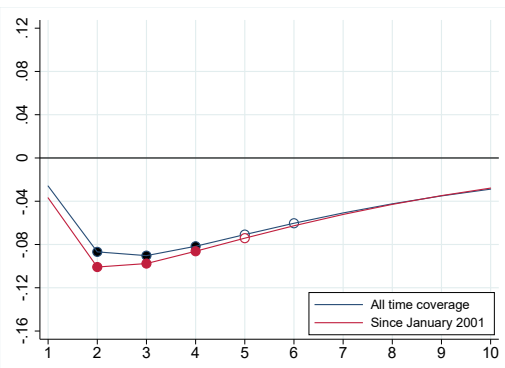

(f) Cinco Dias.

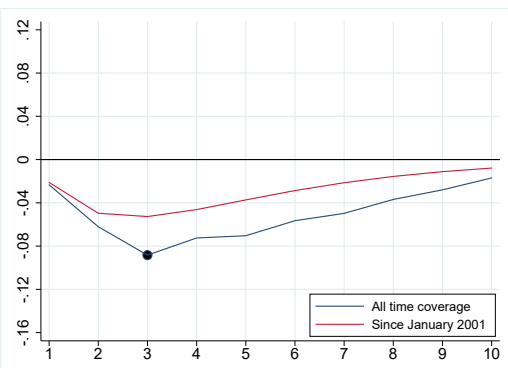

(g) El Economista.

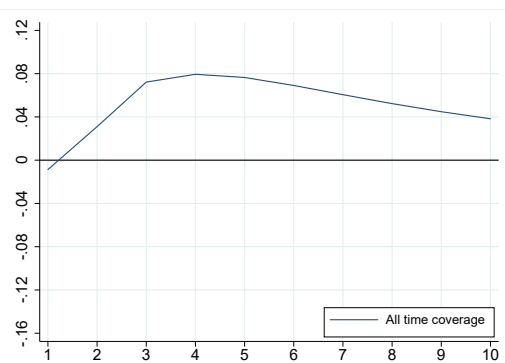

Notes: Each graph shows the impulse response function up to 10 quarters after a positive shock of one standard deviation in the EPU index, based on VAR models described as in Figure 3. In all cases the sample period is defined depending on the availability of the newspaper-specific EPU index (blue lines). For Expansión, Cinco Días, El Mundo, La Vanguardia, and $A B C$, we also run the model by constructing the EPU index from January 2001 onwards (red lines). Full circles indicate statistical significance at 5\%; empty circles indicate statistical significance at $10 \%$; the solid line indicates no statistical significance. 


\title{
BANCO DE ESPAÑA PUBLICATIONS
}

\author{
WORKING PAPERS
}

1801 OLYMPIA BOVER, LAURA HOSPIDO and ERNESTO VILLANUEVA: The impact of high school financial education on financial knowledge and choices: evidence from a randomized trial in Spain.

1802 IGNACIO HERNANDO, IRENE PABLOS, DANIEL SANTABÁRBARA and JAVIER VALLÉS: Private Saving. New CrossCountry Evidence Based on Bayesian Techniques.

1803 PABLO AGUILAR and JESÚS VÁZQUEZ: Term structure and real-time learning.

1804 MORITZ A. ROTH: International co-movements in recessions.

1805 ANGELA ABBATE and DOMINIK THALER: Monetary policy and the asset risk-taking channel.

1806 PABLO MARTÍN-ACEÑA: Money in Spain. New historical statistics. 1830-1998.

1807 GUILHERME BANDEIRA: Fiscal transfers in a monetary union with sovereign risk.

1808 MIGUEL GARCÍA-POSADA GÓMEZ: Credit constraints, firm investment and growth: evidence from survey data.

1809 LAURA ALFARO, MANUEL GARCÍA-SANTANA and ENRIQUE MORAL-BENITO: On the direct and indirect real effects of credit supply shocks.

1810 ROBERTO RAMOS and CARLOS SANZ: Backing the incumbent in difficult times: the electoral impact of wildfires.

1811 GABRIEL JIMÉNEZ, ENRIQUE MORAL-BENITO and RAQUEL VEGAS: Bank lending standards over the cycle: the role of firms' productivity and credit risk.

1812 JUAN S. MORA-SANGUINETTI and ROK SPRUK: Industry vs services: do enforcement institutions matter for specialization patterns? Disaggregated evidence from Spain.

1813 JAMES CLOYNE, CLODOMIRO FERREIRA and PAOLO SURICO: Monetary policy when households have debt: new evidence on the transmission mechanism.

1814 DMITRI KIRPICHEV and ENRIQUE MORAL-BENITO: The costs of trade protectionism: evidence from Spanish firms and non-tariff measures.

1815 ISABEL ARGIMÓN, CLEMENS BONNER, RICARDO CORREA, PATTY DUIJM, JON FROST, JAKOB DE HAAN, LEO DE HAAN and VIKTORS STEBUNOVS: Financial institutions' business models and the global transmission of monetary policy.

1816 JOSE ASTURIAS, MANUEL GARCÍA-SANTANA and ROBERTO RAMOS: Competition and the welfare gains from transportation infrastructure: evidence from the Golden Quadrilateral of India.

1817 SANDRA GARCÍA-URIBE: Multidimensional media slant: complementarities in news reporting by US newspapers.

1818 PILAR CUADRADO, AITOR LACUESTA, MARÍA DE LOS LLANOS MATEA and F. JAVIER PALENCIA-GONZÁLEZ: Price strategies of independent and branded dealers in retail gas market. The case of a contract reform in Spain.

1819 ALBERTO FUERTES, RICARDO GIMENO and JOSÉ MANUEL MARQUÉS: Extraction of inflation expectations from financial instruments in Latin America.

1820 MARIO ALLOZA, PABLO BURRIEL and JAVIER J. PÉREZ: Fiscal policies in the euro area: revisiting the size of spillovers.

1821 MARTA MARTÍNEZ-MATUTE and ALBERTO URTASUN: Uncertainty, firm heterogeneity and labour adjustments. Evidence from European countries.

1822 GABRIELE FIORENTINI, ALESSANDRO GALESI, GABRIEL PÉREZ-QUIRÓS and ENRIQUE SENTANA: The rise and fall of the natural interest rate.

1823 ALBERTO MARTÍN, ENRIQUE MORAL-BENITO and TOM SCHMITZ: The financial transmission of housing bubbles: evidence from Spain.

1824 DOMINIK THALER: Sovereign default, domestic banks and exclusion from international capital markets.

1825 JORGE E. GALÁN and JAVIER MENCÍA: Empirical assessment of alternative structural methods for identifying cyclical systemic risk in Europe.

1826 ROBERTO BLANCO and NOELIA JIMÉNEZ: Credit allocation along the business cycle: evidence from the latest boom bust credit cycle in Spain.

1827 ISABEL ARGIMÓN: The relevance of currency-denomination for the cross-border effects of monetary policy.

1828 SANDRA GARCÍA-URIBE: The effects of tax changes on economic activity: a narrative approach to frequent anticipations.

1829 MATÍAS CABRERA, GERALD P. DWYER and MARÍA J. NIETO: The G-20 regulatory agenda and bank risk.

1830 JACOPO TIMINI and MARINA CONESA: Chinese exports and non-tariff measures: testing for heterogeneous effects at the product level.

1831 JAVIER ANDRÉS, JOSÉ E. BOSCÁ, JAVIER FERRI and CRISTINA FUENTES-ALBERO: Households' balance sheets and the effect of fiscal policy. 
1832 ÓSCAR ARCE, MIGUEL GARCÍA-POSADA, SERGIO MAYORDOMO and STEVEN ONGENA: Adapting lending policies when negative interest rates hit banks' profits.

1833 VICENTE SALAS, LUCIO SAN JUAN and JAVIER VALLÉS: Corporate cost and profit shares in the euro area and the US: the same story?

1834 MARTÍN GONZÁLEZ-EIRAS and CARLOS SANZ: Women's representation in politics: voter bias, party bias, and electoral systems.

1835 MÓNICA CORREA-LÓPEZ and BEATRIZ DE BLAS: Faraway, so close! Technology diffusion and firm heterogeneity in the medium term cycle of advanced economies.

1836 JACOPO TIMINI: The margins of trade: market entry and sector spillovers, the case of Italy (1862-1913).

1837 HENRIQUE S. BASSO and OMAR RACHEDI: The young, the old, and the government: demographics and fiscal multipliers.

1838 PAU ROLDÁN and SONIA GILBUKH: Firm dynamics and pricing under customer capital accumulation.

1839 GUILHERME BANDEIRA, JORDI CABALLÉ and EUGENIA VELLA: Should I stay or should I go? Austerity, unemployment and migration.

1840 ALESSIO MORO and OMAR RACHEDI: The changing structure of government consumption spending.

1841 GERGELY GANICS, ATSUSHI INOUE and BARBARA ROSSI: Confidence intervals for bias and size distortion in IV and local projections - IV models.

1842 MARÍA GIL, JAVIER J. PÉREZ, A. JESÚS SÁNCHEZ and ALBERTO URTASUN: Nowcasting private consumption: traditional indicators, uncertainty measures, credit cards and some internet data.

1843 MATÍAS LAMAS and JAVIER MENCÍA: What drives sovereign debt portfolios of banks in a crisis context?

1844 MIGUEL ALMUNIA, POL ANTRÀS, DAVID LÓPEZ-RODRÍGUEZ and EDUARDO MORALES: Venting out: exports during a domestic slump.

1845 LUCA FORNARO and FEDERICA ROMEl: The paradox of global thrift.

1846 JUAN S. MORA-SANGUINETTI and MARTA MARTÍNEZ-MATUTE: An economic analysis of court fees: evidence from the Spanish civil jurisdiction.

1847 MIKEL BEDAYO, ÁNGEL ESTRADA and JESÚS SAURINA: Bank capital, lending booms, and busts. Evidence from Spain in the last 150 years.

1848 DANIEL DEJUÁN and CORINNA GHIRELLI: Policy uncertainty and investment in Spain.

1849 CRISTINA BARCELÓ and ERNESTO VILLANUEVA: The risk of job loss, household formation and housing demand: evidence from differences in severance payments.

1850 FEDERICO TAGLIATI: Welfare effects of an in-kind transfer program: evidence from Mexico.

1851 ÓSCAR ARCE, GALO NUÑO, DOMINIK THALER and CARLOS THOMAS: A large central bank balance sheet? Floor vs corridor systems in a New Keynesian environment.

1901 EDUARDO GUTIÉRREZ and ENRIQUE MORAL-BENITO: Trade and credit: revisiting the evidence.

1902 LAURENT CAVENAILE and PAU ROLDAN: Advertising, innovation and economic growth.

1903 DESISLAVA C. ANDREEVA and MIGUEL GARCÍA-POSADA: The impact of the ECB's targeted long-term refinancing operations on banks' lending policies: the role of competition.

1904 ANDREA ALBANESE, CORINNA GHIRELLI and MATTEO PICCHIO: Timed to say goodbye: does unemployment benefit eligibility affect worker layoffs?

1905 CORINNA GHIRELLI, MARÍA GIL, JAVIER J. PÉREZ and ALBERTO URTASUN: Measuring economic and economic policy uncertainty, and their macroeconomic effects: the case of Spain.

1906 CORINNA GHIRELLI, JAVIER J. PÉREZ and ALBERTO URTASUN: A new economic policy uncertainty index for Spain.

BANCODEESPAÑA Eurosistema
Unidad de Servicios Auxiliares

Alcalá, 48 - 28014 Madrid

E-mail: publicaciones@bde.es www.bde.es 